\title{
Cytokinin Activity in Storage Organs of Tanier ${ }^{1}$
}

\author{
Miryana Radosevich and Arturo Cedeño Maldonado ${ }^{2}$
}

\begin{abstract}
The radish cotyledon bioassay was used to determine levels of cytokinin activity in storage organs of taniers (Xanthosoma spp.). The material assayed consisted of a mixture of apical and lateral buds separated from mature cormels. This material was separated in fractions by solvent extraction and thin layer cromatography. Cytokinin activity was highest in the organic fraction of petroleum ether. The aqueous phase obtained after separation in this solvent showed inhibitory activity but after further specific organic extraction with ethyl acetate the aqueous phase obtained showed strong growth stimulatory activity.
\end{abstract}

\section{INTRODUCTION}

Taniers (Xanthosoma spp.) are one of the most important starchy crops in Puerto Rico and other countries of the American tropics (1). The marketable portion of the tanier consists of the cormel, an underground storage organ developing from the main corm. Yields from commercially planted taniers are poor and erratic with consequent unfavorable market implications (7).

Plant hormones such as cytokinins are controlling factors in the processes of initiation and development of underground storage organs as has been demonstrated in the potato (6). Knowledge of the cytokinin content of underground tissues such as cormels could lead to the development of methods for increasing yields through hormonal regulation. The present study was conducted to detect the presence and relative activity of cytokinins in the storage organs of tanier as an initial step in determining their role in cormel development.

\section{MATERIALS AND METHODS}

\section{PLANT MATERIAL}

Mature tanier cormels of cultivar "Blanca del Pais" from the Isabela Substation were washed with tap water, and their apical and lateral buds were removed with a razor blade. The bud material obtained was pooled and placed in a sealed container, freeze-dried and kept frozen until used for extractions.

\footnotetext{
${ }^{1}$ Submitted to Editorial Board January 31, 1980 and in revised form August 18, 1982.

${ }^{2}$ Visiting Scientist and Associate Professor, respectively, Department of Horticulture, University of Puerto Rico, Mayagüez, P.R.
} 


\section{FRACTIONING OF PLANT MATERIAL}

We initiated extractions by grinding $100 \mathrm{~g}$ of cold pre-thawed material in a Sorvall Blender ${ }^{3}$ in cold $80 \%$ methanol. The material was then filtered twice through a Buchner funnel and evaporated to near dryness in a rotary evaporator. The aqueous residue was diluted with distilled water to a volume of $250 \mathrm{ml}$ and filtered through a 0.2 micron membrane

\section{ORIGINAL SAMPLE} (80\% Methanol)

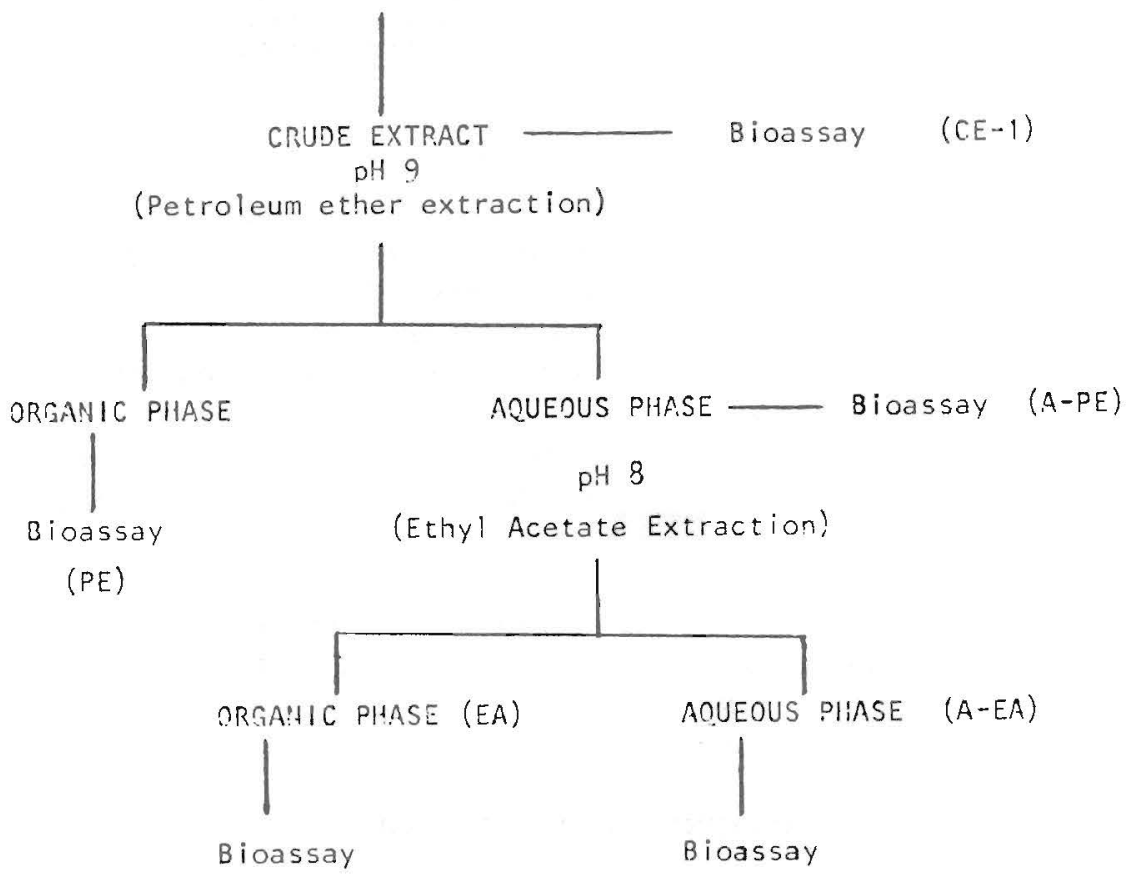

FIG. 1.-Scheme for solvent separation of cytokinin activity in tanier.

filter. The filtrate contained the equivalent of $0.4 \mathrm{~g}$ of bud material per $\mathrm{ml}$ of solution. This extract, $\mathrm{CE}-1$, will be referred to as crude extract. A second batch of crude extract, CE-2, was partially evaporated to $1.0 \mathrm{~g}$ of bud material per $\mathrm{ml}$ of solution. We treated independently two other

${ }^{3}$ Trade names in this publication are used only to provide specific information. Mention of a trade name does not constitute a warranty of equipment or materials by the Agricultural Experiment Station of the University of Puerto Rico, nor is this mention a statement of preference over other equipment or materials. 
batches of crude extracts, CE-3 and CE-4, by adjusting their $\mathrm{pH}$ to 9.0 with $\mathrm{NaOH}$ and extracted three times with equal volumes of petroleum ether. The aqueous (A-PE) and the petroleum ether (PE) phases were vacuum-evaporated to dryness and each diluted with distilled water to $0.4 \mathrm{~g}$ bud material per $\mathrm{ml}$ of solution. One of the two aqueous phase fractions (A-PE) was acidified to $\mathrm{pH} 3.0$ with $\mathrm{HCl}$ and extracted four

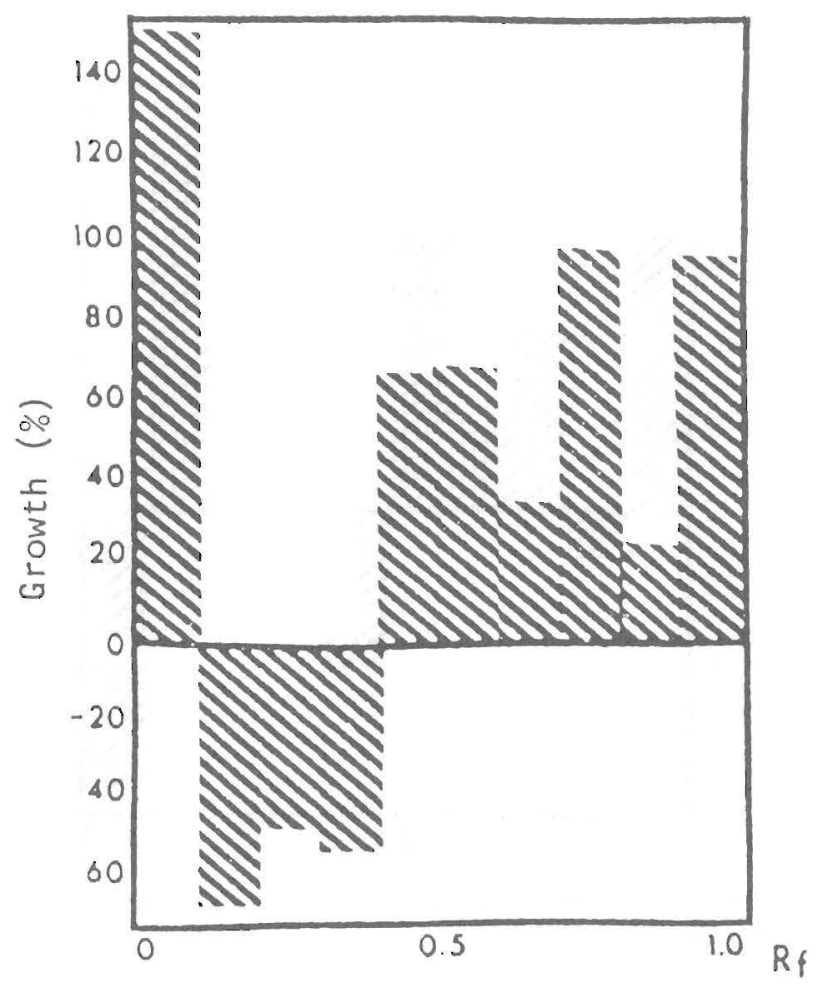

FIG. 2.-Cytokinin activity in fraction obtained by cellulose thin layer chromatography with solvent system (a).

times with equal volumes of ethyl acetate. The organic (EA) and the aqueous (A-EA) phases were evaporated to dryness and each diluted with distilled water to $0.4 \mathrm{~g}$ bud material per $\mathrm{ml}$ of solution. The scheme presented in figure 1 summarizes the fractioning of the plant material and the analytical destination of each separate sample.

The petroleum ether fraction of the crude extract $(\mathrm{PE})$ was further fractioned by thin layer chromatography on $20 \times 20 \mathrm{~cm}$. cellulose plates (Kodak 6064, with and without fluorescent indicator) and on silica gel 
plates with fluorescent indicator. Chromatograms were developed with the following solvent systems:

(a) butanol: acetic acid: water $(4: 1: 1 \mathrm{v} / \mathrm{v})$

(b) butanol: $25 \%$ ammonia $(4: 1 \mathrm{v} / \mathrm{v})$

The chromatograms were cut in thin strips and components eluted in a small amount of $80 \%$ methanol ( 3 to $5 \mathrm{ml}$ ). The solvent was evaporated and the volume substituted with $5 \mathrm{ml}$ water. Figures 2 to 4 show the histograms obtained.

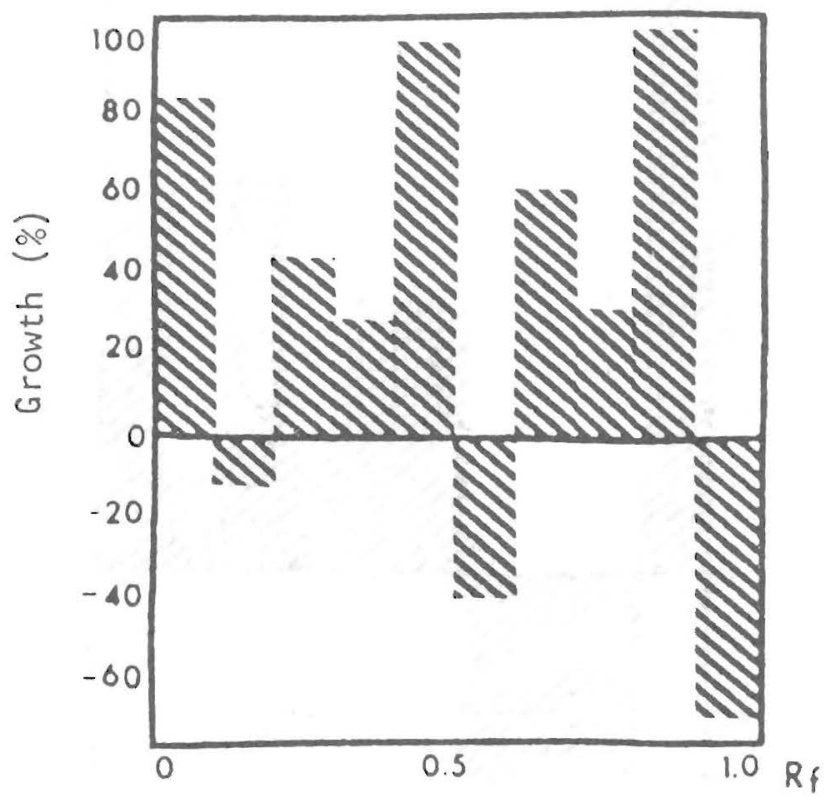

FIG. 3.-Cytokinin activity in fraction obtained by silica gel thin layer chromatography with solvent system (b).

\section{COTYLEDON EXPANSION BIOASSAY}

The radish cotyledon expansion test, essentially as described by Lethan (5) was used as the bioassay to determine the cytokinin activity in the fractioned plant material. The cotyledons were cultured for 5 days instead of three.

Each fraction was bioassayed three times at its original concentration and at $10^{-1}, 10^{-2}$ and $10^{-3}$ dilutions. Table 1 shows the average results obtained. The relative cytokinin activity is expressed as percentage of increase in weight in relation to the controls (cotyledons grown in distilled water) according to the following formula:

$$
\%=\frac{\mathrm{Wf}-\mathrm{Wi}}{\mathrm{Wi}}
$$


where

$$
\begin{aligned}
& \mathrm{Wf}=\text { final weight } \\
& \mathrm{Wi}=\text { initial weight }
\end{aligned}
$$

\section{RESULTS}

Of all fractions assayed, the petroleum ether organic fraction showed the highest cytokinin activity, the aqueous ethyl acetate fraction follow-

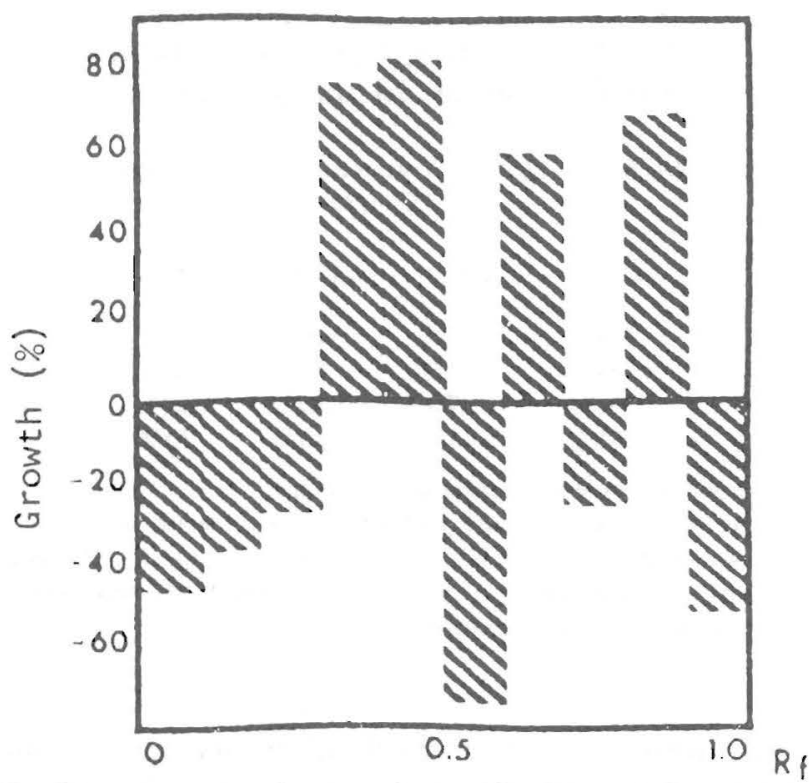

FIc. 4.-Cytokinin activity in fraction obtained by silica gel thin layer bi-dimensional chromatography with solvent systems (a) and (b).

ing. The cytokinin activity of the crude extract was relatively low compared to that of the organic extractions (table 1).

Cellulose thin layer chromatography of the petroleum ether fraction (PE) with solvent system b showed the highest cytokinin activity at Rf $0.1,0.5,0.6,0.8$, and 1.0. Inhibitory zones were found at $\operatorname{Rf} 0.2,0.3$, and 0.4 (fig. 2). When the petroleum ether fraction was chromatographed on silica gel thin layer plates with solvent system $\mathrm{b}$, activity exceeding $85 \%$ was obtained at $\operatorname{Rf} 0.1,0.5$, and 0.9 with the highest degree of inhibition at Rf 0.6 and 1.0 (fig. 3). Bidimensional chromatography on silica gel of a similar extract allowed determination of activity exceeding $70 \%$ at $\mathrm{Rf}$ $0.4,0.5$, and 0.9 . Inhibition exceeding $37 \%$ was obtained at $\mathrm{Rf} 0.1,0.2$, 0.6 , and 1.0 (fig. 4). 


\section{DISCUSSION}

In the present work we show the presence of cytokinin-like activity and of growth inhibitory activity in extracts from tanier storage organs. These substances could, in part, contribute to the endogenous regulation of the processes leading to cormel initiation and growth. In other reports concerning cytokinin extraction from other types of plant material cytokinin activity was highest in the aqueous phases of petroleum ether and ethyl acetate $(2,3)$. In the latter solvent, a separation of activity between the aqueous and organic phase has been obtained by Hemberg (4).

In the case of tanier bud extracts, highest activity was obtained in the organic phase of petroleum ether. In the present study the petroleum

TABLE 1.-Cytokinin activity in the crude extract and partially purified fractions of bud material from tanier ${ }^{1}$

$\begin{array}{lrrrrrr}\begin{array}{c}\text { Concen- } \\ \text { tration }\end{array} & C E-1^{3} & C E-2 & A-P E & P E & A-E A & E A \\ 10^{\circ} & 124 \% & 6 \% & -46 \% & 287 \% & 211 \% & 59 \% \\ 10^{-1} & 84 \% & 91 \% & 68 \% & 109 \% & 140 \% & 75 \% \\ 10^{-2} & -4 \% & 37 \% & 25 \% & 60 \% & 113 \% & 2 \% \\ 10^{-3} & -35 \% & -17 \% & -10 \% & 51 \% & 6 \% & 24 \%\end{array}$

${ }^{1}$ Activity expressed as percentage increase in weight.

${ }^{2}$ Concentrations of crude extract and partially purified fractions.

${ }^{3} \mathrm{CE}$-1: crude extract $\left.(0.4) \mathrm{g} / \mathrm{ml}\right)$; CE-2: crude extract $(1 \mathrm{~g} / \mathrm{ml})$; A-PE: aqueous phase of petroleum ether; EP: organic phase of petroleum ether; A-EA: aqueous phase of ethyl acetate; EA: organic phase of ethyl acetate.

ether aqueous phase fraction showed inhibitory activity, but after its extraction with ethyl acetate the aqueous fraction obtained showed very strong stimulatory growth activity, an indication that separation or inactivation of inhibitors was obtained. Since the ethyl acetate organic phase fraction also showed stimulatory effects a partitioning of cytokinin activity as predicted by the results of Hemberg (4) was obtained.

\section{RESUMEN}

Se utilizó la prueba del cotiledón del rábano para determinar los niveles de actividad de citocininas en los cormos secundarios de la yautia (Xanthosoma spp.). El material estudiado consistió de una mezcla de yemas apicales y laterales que se obtuvieron de cormos secundarios bien desarrollados. Este material se separó en fracciones mediante extracción con diferentes disolventes y separación por cromatografia de capa fina. Se obtuvo mayor actividad asociada de citocininas en la fracción de la fase orgánica de éter de petróleo. La fracción acuosa mostró actividad inhibi- 
toria, la cual fue separada mediante éter de petróleo observándose entonces un marcado estímulo en crecimiento asociado a citocininas.

\section{LITERATURE CITED}

1. Beale, A. J., Green, V. E. and Porrado, J. L., 1982. Inducement of flowering in taniers (Xanthosoma spp.), J. Agric. Univ. P.R. 56 (2) 115-22.

2. Blumenfeld, A. and Gazit, S., 1970. Cytokinin activity in avocado seeds during fruit development, Plant Physiol. 46: 331-33.

3. Gupta, G. R. and Maheshwari, S. C., 1970. Cytokinins in seeds of pumpkin, Plant Physiol. 45: 14-8.

4. Hemberg, T., 1974. Partitioning of cytokinins between ethyl acetate and acid-water phases, Physiol. Plant. 32: 191-92.

5. Letham, D. S., 1971. Regulators of cell division in plant tissues XII. A cytokinin bioassay using excised radish cotyledons, Physiol. Plant. 25: 391-96.

6. Palmer, C. E. and Smith, O. E., 1969. Cytokinins and tuber initiation in the potato tuber Solanun tuberosum L., Nature 221: 79-80.

7. Puerto Rico Department of Agriculture, 1980. Facts and Figures on Puerto Rico's Agriculture. 